\title{
Business Administration Training For SME Women in Menur Pumpungan Village
}

\author{
Author \\ Widhi Ariestianti R (Orcid ID. 0000-0001-5890-6292), \\ Siti Rokmi Fuadati (Orcid ID. 0000-0002-0489-3462), \\ Ulfah Setia Iswarah (Orcid ID. 0000-0003-3256-1120), \\ Teguh Gunawan (Orcid ID. 0000-0003-3526-5335) \\ Correspondence \\ Sekolah Tinggi Ilmu Ekonomi Indonesia (STIESIA) Surabaya \\ Email: widhiariestianti@stiesia.ac.id
}

\begin{abstract}
Community service activities are carried out to provide administrative training to women who are MSMEs and menur pumpungan villages. Administration training provided in the form of training and assistance in the preparation of simple bookkeeping and business ethics in running a business. Training activities and assistance in preparing simple books is important so that mothers can know with certainty how much business revenues and business expenses are run. In addition to the existence of simple bookkeeping can be known the number of items that sell. Business ethics training is conducted to provide provisions for SMEs to be confident in marketing goods that are sold according to existing conditions so that consumer confidence can be achieved. The results of this activity can be concluded that UMKM mothers have understood the importance of bookkeeping and can begin to compile simple bookkeeping in their business by continuing to be accompanied by a team. In business ethics training, mothers have understood the importance of giving consumers rights. This is shown by mothers who want to redesign packaging labels that include more information for consumers such as expiration date, composition of materials used and the date of production of the product.
\end{abstract}

Key words: Training and Mentoring, SMEs Woman, Business Administration

Received: 01 April 2020. Accepted: 04 August 2020

\section{Introduction}

Mother in the household is the backbone that ensures that the family can run well or not. The role of housewives in this modern era has many roles, among others, also helping the family economy in between the free hours they have. Many housewives who have businesses in addition to filling free time also help improve the family's economy. Businesses that are run in general are businesses that are based on daily skills owned for example in culinary, sewing, handicraft and so on.

Although in the form of micro, small and medium businesses, this business is a business that is resilient to economic problems. This is because the business that is done is made from local raw materials, independently managed and the market of the business carried out is the surrounding community. The Menur Pumpungan subdistrict is one of the sub-districts in Sukolilo 
sub-district which has many women who have independent businesses. There are businesses that work in collaboration with other parties, but there are also those that are marketed independently both through the off line market and online market.

The business undertaken can be said to be quite developed but the problem that exists is that the MSME perpetrators have not kept a record of the business being run. This has an impact on the difficulty of detecting business development so far. In addition, how the fulfillment of consumer rights also needs to be improved.

Fulfillment of consumer rights such as clear information about the products produced is part of business ethics. When the business is carried out in accordance with existing ethics it will have an impact on increasing income for producers (Galuh, 2018). This increase in income was partly due to increased consumer confidence in the product because basic information that was important for consumers had been given.

For the producers themselves, knowing the development of the business carried out by monitoring how much is generated per day and how much income is important. If information like this is owned then business development planning can be done. This lack of documentation is a classic problem faced by MSME mothers. Some of the benefits obtained by women who are MSMEs who carry out simple bookkeeping are in the first instance, women have the latest financial information about businesses that are run at any time. Second, it can provide information about the financial condition of financial operations in a given accounting period. Third, mothers can have information about products that have the greatest interest and future development plans (Rivai, 2003).
Seeing the importance of simple bookkeeping for the business that is run, it is important for the MSME entrepreneurs to carry out this administrative activity.

\section{Method}

In carrying out community service activities there are a number of steps taken, namely:

a. Consulted with Sukolilo sub-district, especially on the economy section

b. Consult with the Menur Pumpungan subdistrict as well as surveying the problems faced by the MSME perpetrators.

c. Prepare training materials that are easily understood by mothers and in accordance with the needs of MSME perpetrators

d. Conduct business ethics training and the importance of simple bookkeeping

e. Assist the preparation of simple bookkeeping and labels on the packaging

f. Evaluate and supervise the activities carried out.

\section{Results and Discussion}

This activity aims to provide training and assistance in the preparation of simple bookkeeping and increasing understanding of the importance of business ethics for MSME entrepreneurs in the Menur Pumpungan village.

The implementation of community service activities is carried out in three stages, namely the first stage, training in business ethics and simple bookkeeping, the second stage of mentoring for the preparation of simple bookkeeping and discussions on updating the label, the third evaluation of the activities carried out.

In the first stage, training is conducted on the types of bookkeeping, the benefits of bookkeeping and how to prepare books. This 
activity is carried out by inviting the MSE actors to the STIESIA classrooms in Surabaya. The selection of this place is done to better socialize campus life for local residents. In addition, training activities also continued on the concept of business ethics, the benefits of running an ethical business, and examples of ethical business activities that can be carried out without increasing the burden of production costs. This activity was also filled with discussion about it. From the discussion activities, the potential of each UMKM can be explored and the problems faced are related to the business administration activities carried out. This activity was attended by 15 MSME perpetrators. The implementation of this activity was also supported by the Head of the Menur Pumpungan Village and the District Head of Sukolilo District.

The second stage, carried out after one month the first phase of activities carried out. This activity was carried out in the form of assistance in the preparation of simple bookkeeping and discussions on label renewal which contained concise and clear product information. This activity is carried out by involving the accompanying students. The accompanying students are tasked with assisting the women in preparing simple bookkeeping but still under the supervision of the lecturers who carry out community service activities, as well as the label renewal activities carried out by several MSME mothers.

In the third stage, the evaluation and supervision phase is carried out exactly one month after the Phase 2 activities are carried out. The monitoring and evaluation activities were carried out by sampling a number of
MSME perpetrators. From the evaluation and supervision activities it can be seen that only a few women routinely carry out simple bookkeeping activities on a weekly basis and the other participants choose to do the preparation on a monthly basis in their free time. For mothers who did the renewal on the packaging labels, some mothers already had new packaging labels and some were still in the printing process. This condition is because mothers still want to use the rest of the label that they had before. This activity will not stop here because this activity is the first step in the process of forming a cake village in the Menur Pumpunga village. From the results of this activity, it is known that the Menur Pumpungan village has the potential to be formed as a cake village because many MSME women produce good quality cakes but are still not neatly organized.

\section{Conclusion}

The independent activities of MSMEs in Menur Pumpungan Village must be supported and their potential explored. Continued efforts are needed to continue to convince mothers that bookkeeping is important for a business as well as clarity of information on a product produced. The use of technology to compile simple bookkeeping is an important thing to do for young mothers of MSME actors. For elderly women, it is important to keep track of business expenses and revenues in a consistent manner so that business development can be monitored. Improvement of business ethics for the future is not only on the label but how to convey to consumers and deal with suppliers is also important for the smooth running of business and business development. 


\section{References}

Ali, S, F. Inggriyani, dan D.M.Pauzy. 2018. Pelatihan Pembukuan Sederhana Bagi Pelaku Usaha Kerajinan Anyam Mendong di Kecamatan Rajapolah Kabupaten Tasikmalaya. http://repository.unpas.ac.id/36088/1/a rtikel\%20pembukuan\%20sederhana.p df (30Maret 2020; $12.30 \mathrm{Wib}$ ).

Ayyubi,S.E, dan S.A.Anggraini. 2016. Peran Etika Bisnis Islam Terhadap Kinerja Usaha Mikro, Kecil,dan Menengah (UMKM) Pangan di Kota Bogor. Journal of Business and Banking 6(2);183-194

Galuh,K. 2018. Pentingnya Etika Dalam Pertumbuhan Usaha Mikro Kecil dan Menengah di Era Global. http://eprints.umsida.ac.id/3474/ maret 2020; $10.30 \mathrm{Wib}$ )

Laily, N,Y. Sidharta, dan A. Djuraidi. 2020. Simple Booking Training For Batik Jonegoro Wirausahawan Women In Bojonegoro District. Kontribusia 3(1).

Rivai, V. 2013. Commercial Bank Management: Manajemen Perbankan dan Teori ke Praktik. Edisi 1.Cetakan 1. Jakarta: Rajawali Pers.

Yshinta, A.N. 2017. Pelatihan Pencatatan Keuangan Untuk Usaha Kecil. http://staffnew.uny.ac.id/upload/13231 8570/pengabdian/pelatihanpencatatan-keuangan-untuk-usahakecil.pdf (30 Maret 2020;11.30 Wib) 